\title{
WILEY

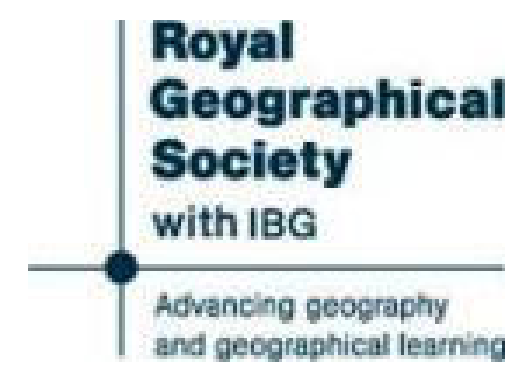

Inference Applied to Geography, with Special Reference to Ocean Currents and the Arctic Regions

Author(s): General Hauslab

Source: Journal of the Royal Geographical Society of London, Vol. 45 (1875), pp. 34-45

Published by: Wiley on behalf of The Royal Geographical Society (with the Institute of British

Geographers)

Stable URL: http://www.jstor.org/stable/1798704

Accessed: $31 / 12 / 2014$ 03:16

Your use of the JSTOR archive indicates your acceptance of the Terms \& Conditions of Use, available at

http://www.jstor.org/page/info/about/policies/terms.jsp

JSTOR is a not-for-profit service that helps scholars, researchers, and students discover, use, and build upon a wide range of content in a trusted digital archive. We use information technology and tools to increase productivity and facilitate new forms of scholarship. For more information about JSTOR, please contact support@ jstor.org.

Wiley and The Royal Geographical Society (with the Institute of British Geographers) are collaborating with JSTOR to digitize, preserve and extend access to Journal of the Royal Geographical Society of London. 
II.-Inference applied to Geography, with special reference to Ocean Currents and the Arctic Regions. By General HausLab, Vienna, Honorary Corresponding Member R.G.s.

Looking to the high interest just now attaching to the unknown Polar regions, I propose in this paper to venture upon certain deductions with respect to them, and thus to apply deductive inference to the solution of a geographical problem.

In doing so I shall largely avail myself of maps and diagrams; for in starting hypotheses it is easy enough to make assertions which would not bear the test of being embodied in a diagram. What should hinder us, for instance, from asserting: that there is such a thing as a square circle, though an endeavour to draw one must inevitably lead to failure?

In discussing this subject, I must first of all inquire into the natural laws governing the motion and currents of water, and trace the anomalies between rivers and the sea.

Fig. 1, Plate I., shows the bottom of the Adriatic, which is perfectly well known. It will be observed that it consists of three distinct basins, separated by three submarine plateaux," the position of which is indicated on the Italian and eastern shore by striking promontories or headlands.

A river flowing over a country having such a configuration would naturally form its channel along the deepest parts, as shown in Fig. 2, but not so an ocean current. The latter actually runs close along the Dalmatian coast to the north, and then returns along the coast of Italy to the south (Fig. 3). The explanation of this phenomenon is as follows:-

The Greek current coming from Corfu strikes the submarine plateau, which extends from Brindisi to Capo Linguetta. There it bifurcates; one portion being turned back towards Capo di Santa Maria, the southern cape of Otranto, the other flowing over the plateau into the first basin referred to. The latter, in accordance with its vis inertia, ought to continue its direct course towards Brindisi, but a current flowing to the west of it (and to be referred to presently) presses it towards the coast of Dalmatia.

It continues along this coast until, beyond Cattaro, it encounters the second platean, which extends from Monte Gargano to the Isola Lagosta. There it again bifurcates; one portion turning back to join the current running along the

* The northermmost of these, that between Ancona and Istria, is not very distinctly shown on our ehart, lecause it lies between two contour-lines. 
Fig. 1.

APPEARANCE OF THE BOTTOM OF THE ADRIATIC SEA
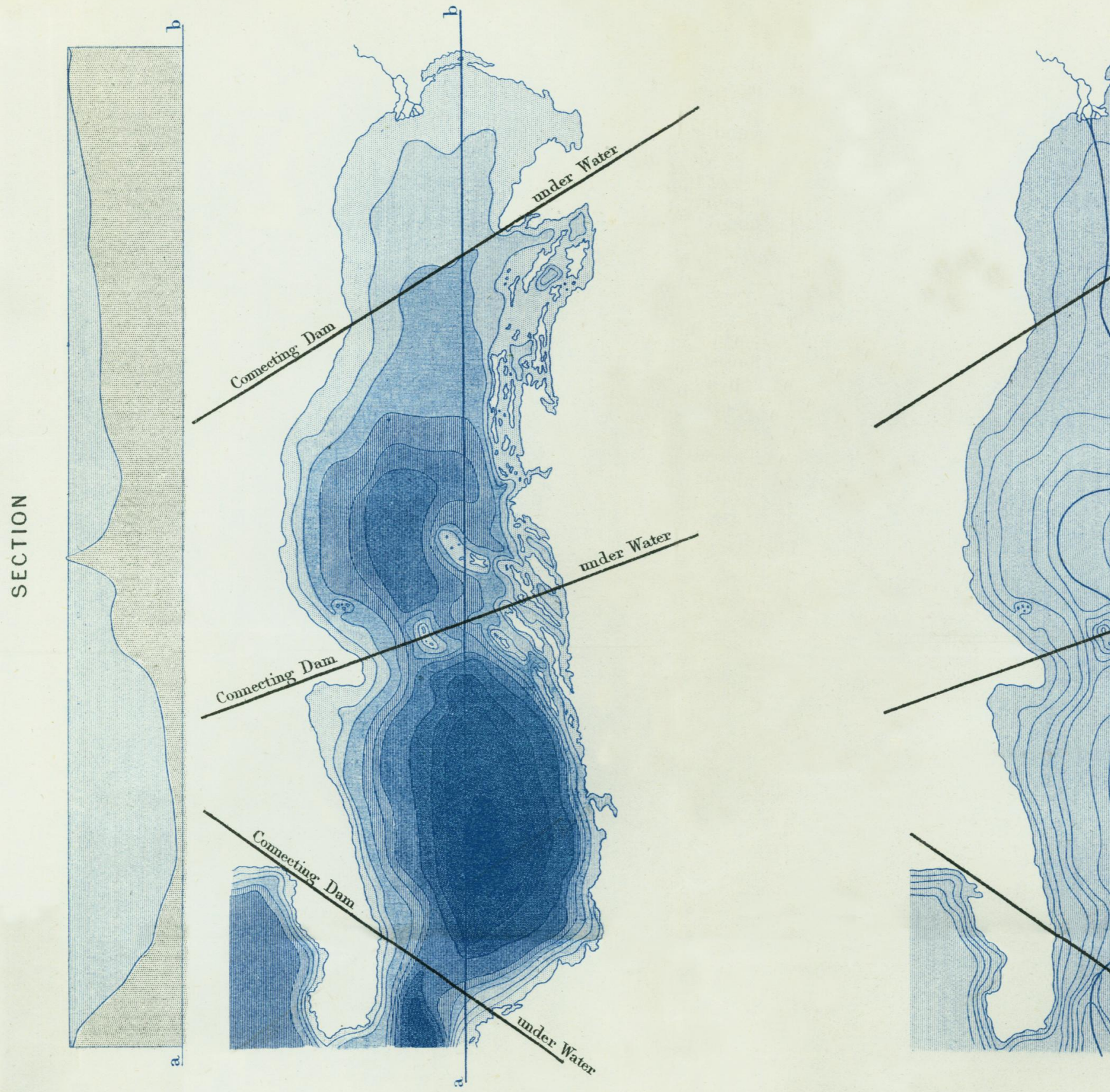

Published for the Journul of the Regral Geogmphical Society by Jo 
Fig. 2.

Fig. 3.

\section{CURRENTS IN THE ADRIATIC SEA}

Plate 1.

to face page 34

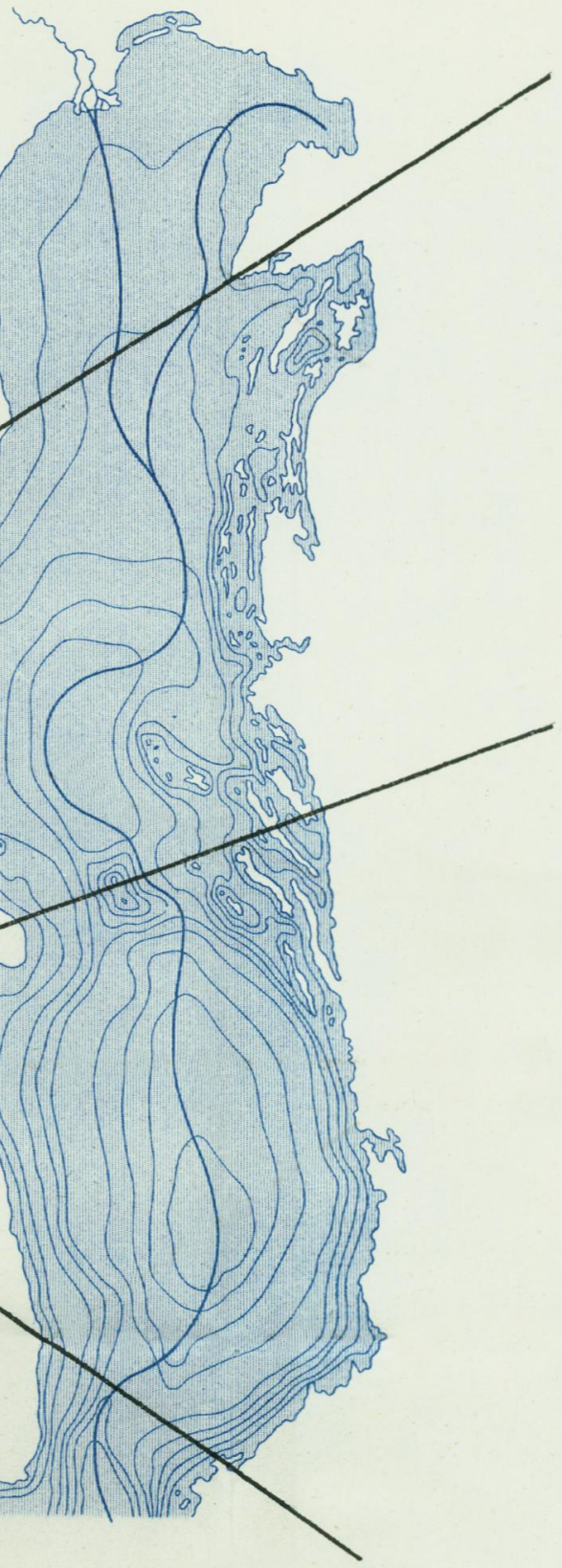

Society by John Murvay: Albemarile Street 1875.

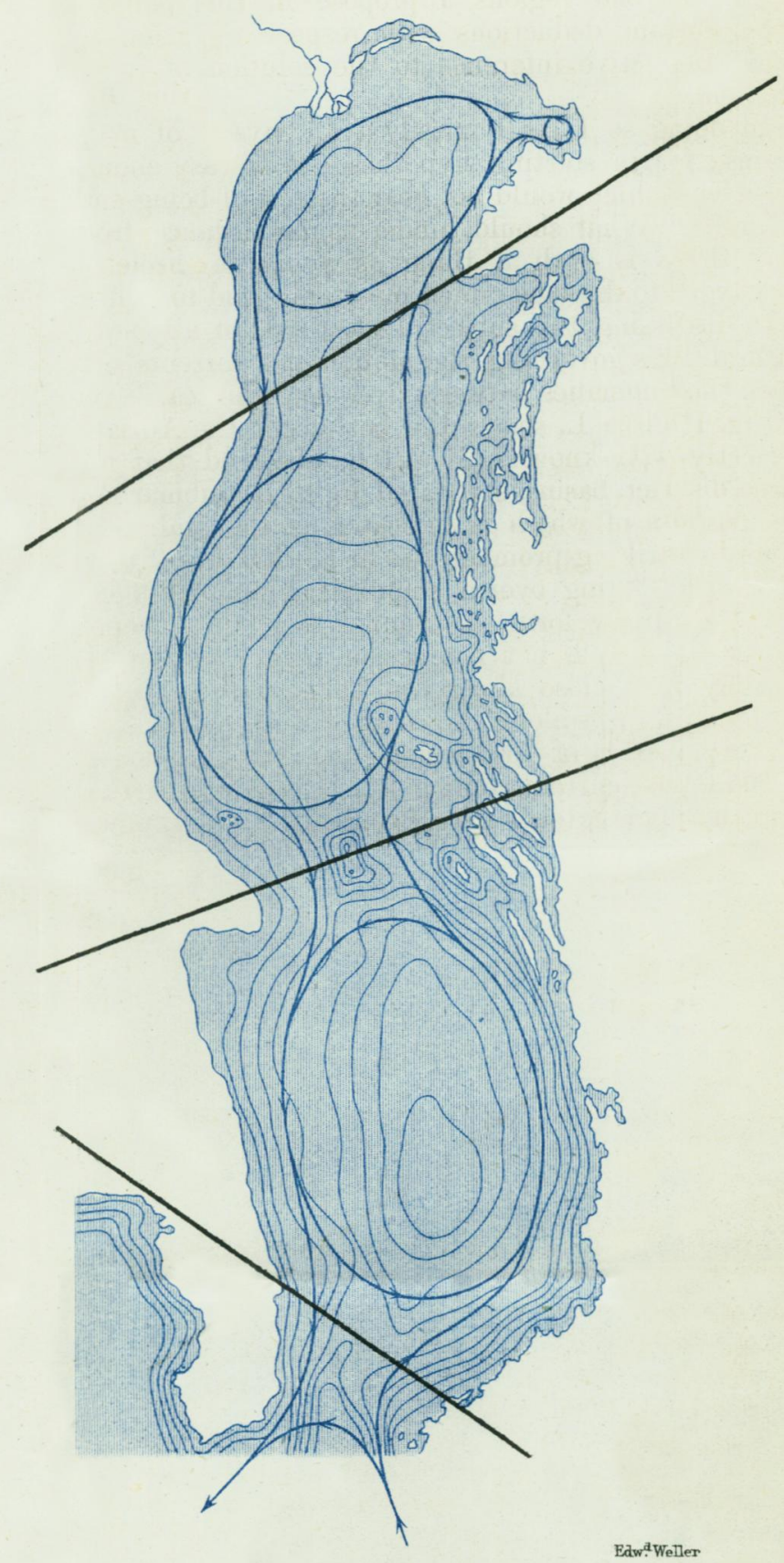


Italian coast, the other crossing the plateau and continuing to flow to the north. The Italian current, after receiving this reinforcement, is not able, in its southerly course, to cross the plateau between Brindisi and Capo Linguetta, but a portion of it is diverted towards the Dalmatian coast; and thus is formed the eddy or circuit current within the southernmost of the three basins. That portion of the Dalmatian current which crosses the plateau between Monte Gargano and the Isola Lagosta meets the platean extending between Ancona and Istria, bifurcates, and is thus the cause of a similar circuit-current in the centre basin. A third circuit current is formed in a similar manner in the northernmost basin, and minor currents and circuits, all due to the action of the same law, are met with between the numerous islands skirting the coast.

If we look at the general features thus presented by the Adriatic, we find that there are three principal circuit currents indicating the positions of the three basins, and separated by four-sided figures having their sides curved inwards, and bounded by currents flowing in contrary directions. These latter indicate the positions of the plateaux. Let us impress upon the mind these features, in order that we may recognise them should we meet with them in other parts of the globe.

The phenomena of these Adriatic currents are well known, but they can neither be explained by the law of gravitation nor by the rotation of the earth; for though the waters are pressed upon the coasts, both towards the east and west, the general direction of their circulation is north and south.

We must, therefore, seek for some other cause to explain their existence.

A simple experiment with a glass of water proves to us that, owing to the mobility of its molecules, water does not simultataneously follow the movements of the vessel containing it. This retardation, producel by the earth's rotation, is assumed to explain satisfactorily the westerly equatorial currents.

But the earth does not merely rotate, it also oscillates, owing to what is known as the nutation of the earth's axis. The water, not being capable of following this movement, however small, lags behind, and thus currents are produced.

If we cause a basin containing water to oscillate in four directions, the water will describe an eddy or circuit current.

This leads me to the conclusion that the circuit currents of the Adriatic are due to the nutation of the earth's axis.

Let us now compare the currents of the Adriatic with those of the Ocean.

A warm easterly current flows from the Indinn Ocean. At D 2 
Madagascar it bifurcates. One branch turns north, passes to the south of Ceylon, and rejoins the parent current near Sumatra; thus forming a circuit. The second branch continues to the Cape of Good Hope, where it bifurcates, one branch running up the western coast of Africa; the other, having joined a cold easterly current, flows to Australia, and thus likewise completes a circuit.

The cold north-easterly current referred to bifurcates to the south of the Cape, sending one branch to the east, and the other to the north; and thus forming a four-sided figure with sides curved inwards, such as we have already observed in the Adriatic.

The combined Jndian and Antarctic current flows north along. the west coast of Africa, gradually increasing in temperature as it approaches the equator. On meeting the eastern promontory of South America, this current bifurcates; one branch flowing south, along the east coast and then towards the east, past Tristan da Cunha, thus constituting a South Atlantic circuit current.

To the north of the equator, owing to the predominating influence of rotation, the law is modified, but only in as far as the direction of the currents becomes retrograde. The second branch of the African current, after having traversed the submarine plateau joining Africa and America, does not flow east to Spain and Ireland, and then describe its circuit by following the coasts of Newfoundland and the east coast of North America, but, owing to the influence of rotation, it enters the Gulf of Mexico and gives rise to the warm Gulf Stream. The latter flows in an easterly direction towards Europe, sends one branch to the coast of Ireland, and another past Portugal and Africa, and thus forms the circuit of the North Atlantic.

North of the submarine plateau which joins Ireland to Newfoundland, the influence of rotation ceases, and the currents therefore flow north along the eastern coasts of Scotland and Norway to Novaya Zemlya, and then turn back to the south, past the southern extremity of Spitzbergen, along the west coast of Greenland, as far as Cape Farewell, and thence to Newfoundland. Where these currents flow over the two submarine plateaux connecting Norway, the Faroe Islands, Iceland and Greenland, and the North Cape, Bear Island and Spitzbergen, we again observe the four-sided figures referred to, whilst the intervening basins are traced out by circnit currents.

Davis Strait and Baffin Bay furnish almost an exact counterpart to the currents of the Adriatic.

In the Pacific, two equatorial currents are produced by rotation; and there are circuit currents in the south and north 
basins of that ocean, the latter sending off a warm branch through Behring Strait into the Polar basin.

In the Pacific, as in the Indian Ocean, the preponderance of rotation modifies our law; and the currents in its northern basin are retrograde.

In the comparatively undisturbed centres of all these circuit currents, accumulations of fucus are met with, and where these arẽ found, we may infer from them the existence of a circuit current.

There remain to be explained the East-Equatorial countercurrents.

The assertion that the surface of water is horizontal, is true only of water in a state of perfect repose. Every movement causes the water to form cavities and elevations, varying in degree according to the forces acting upon it; and in that condition water will flow, not only downwards, but likewise upwards.

If we stir a glass of water with a spoon, a funnel is formed in the centre, more or less deep, according to the rapidity of our movement.

When impelled by a force acting from belind, or when subjected to the attraction of the sun and moon, water moves upwards, i.e., to more elevated places.

Every fountain, and the rise of the flood-tide, prove this.

A rise or swell of water may be causerl by pressure from the rear or an attractive force in front. In this case, the molecules impelled at a less rapid rate slide down on the sides.

If there are two such "swells" parallel to and at some distance from each other, a cavity or channel will be formed between them, into which the molecules slide from the top of each swell.

This fact may possibly explain the easterly direction of the counter-currents of the Atlantic and Pacific, enclosed as they are by two westerly rotation-currents, which swell on coming into contact with the East and West India Islands.

The currents in the Gulf of Arabia, the Bay of Bengal, and in the Indian Ocean generally, vary according to season, probably in consequence of the variable direction of the monsoons.

Lastly, the remarkable fact of the heavier cold Polar current dipping under the lighter southerly current near Newfoundland is deserving of attention. The measurements of the Challenger have shown that this retrograde under-current Hows at an inconsiderable depth below the surface of the sea near Halifax and New York, and that its direction is subject to the same laws as that of the surfacc-currents.

The rotation of the earth impels it towards the coast of 
America, for near Sombrero it is much nearer the surface thali at Tenerife. It likewise, on coming from the north, strikes the submarine plateau joining Africa and America, which causes it to bifurcate. Its western branch crosses the plateau, and rises to the surface near Pernambuco and the Abrolhos Islands; whilst its retrograde branch, as far as lat. $3^{\circ} 8^{\prime}$ N., long. $14^{\circ} 49^{\prime} \mathrm{w}$. of Greenwich, is at a far less depth than in the centre of the North-Atlantic basin and at St. Vincent; and it consequently rises to the surface to join the equatorial rotation-current.

In the North-Atlantic basin, the cold southerly deep-sea current runs in a direction contrary to that of the warm northerly surface-current; whilst in the South-Atlantic basin both run in the same direction, the water under the equator being thus replenished from the south, and the retrograde movement effecting a thorongh circulation of the waters of the globe.

We are thus able to form a general conception of all oceancurrents, and find that phenomena, like those observed in the Adriatic, recur everywhere, and depend therefore upon the same law.

On further consideration, we cannot fail being struck by a number of instances in which currents rum in the same direction.

The currents along the west coasts of Ireland and England run to the north ; on the east coasts of these islands they run south. In the Channel the currents are modified by the tides, so as to follow its direction; flowing sometimes to the west, at others to the east. The currents encircling Iceland, Spitzbergen, and Novaya Zemlya, likewise ascend along the western shores, and descend along the eastern. It would therefore appear that in the North Atlantic, the effects of rotation not any longer predominating, currents, as a rule, and in accordance with the law referred to, flow in a northerly direction along the western coasts of the islands, double these islands in the north, and return south along the eastern coasts; and that the circuit-currents in the basins between them flow in the contrary direction, that is east, north, west, and south.

It is very much to be regretted that observations on oceancurrents are comparatively rare and frequently untrustworthy, and that due attention has not hitherto been bestowed upon this subject.

It results from all that has been stated that currents, and the movement of water generally, cannot be traced to a single cause, but are the product of several factors, whose influence varies. These factors are:-

Gravitation (which impels water to seek the lowest level). 


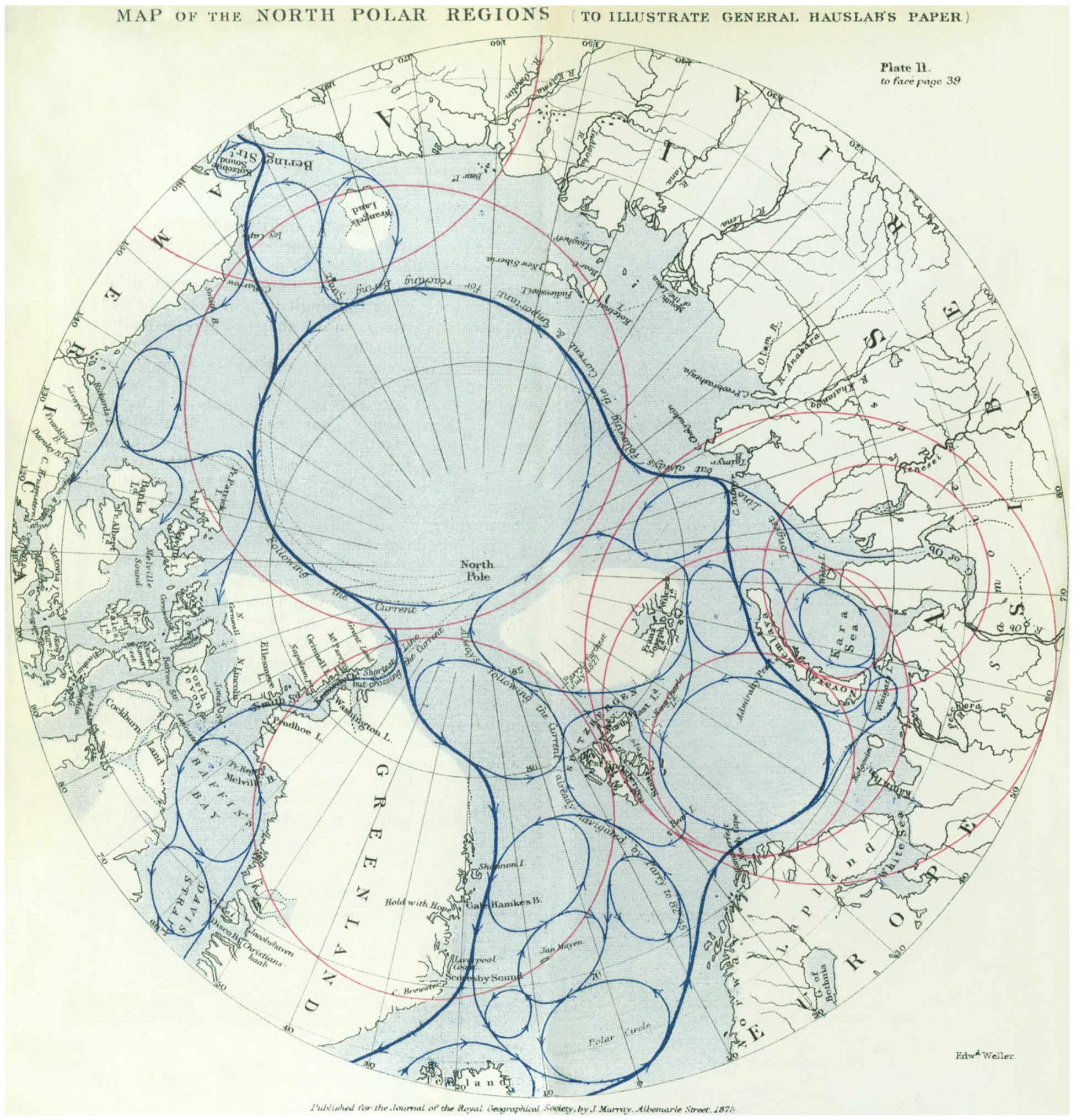


The configuration of the sea-bottom.

The rotation of the earth.

The nutation of the earth's axis.

Pressure applied from the rear.

The attraction of sun and moon.

The temperature of the sea-water.

The direction of the winds.

The disturbance of the equilibrium and its restoration.

The salinity of the sea-water (its specific weight) is likewise said to exercise some influence.*

Before I venture upon deductive inferences respecting the unknown Polar regions, I beg to submit to your notice a second law of nature respecting the outward shape of the inequalities of the earth's surface, which I first explained at a meeting of the Imperial (Austrian) Academy of Sciences, a short time ago.

'This law is as follows:-By prolonging certain mountain chains, and connecting them with isolated heights in a natural manner, we are able to prove, by reference to maps, that there existed on the earth's surface annular mountain chains, similar to those discovered on the moon; that these chains are proportionate in size to the size of our planet; and that both, those of the moon and of the earth, must therefore owe their origin to the operation of the same law.

I advisedly eschew the use of terms such as volcano and crater, which point to origin, and use that of annular mountain chains instead, which applies merely to configuration.

The curved chains of the Aleutian Islands, the Kuriles, the Japanese Islands, the Marianas, the West and East Indian Islands, the circular shape of China, of North-Western Africa and the river-basin of the Amazonas and Orinoco are amongst the most striking instances attesting the existence of such annular mountain chains.

If we complete the circle of which the Alentians form an arc, it will be found to cross Barrow Point and the Cape near the Medvieshi Islands, and this proves that the law referred to has operated in the Arctic Regions also.

In former ages these annular mountains were submerged, flooded, which partly caused their destruction, and all that remains of them are mere fragments which we are obliged to search for and put together.

Plate II. A circle passing through Behring Strait, Iceland, and the Isthmus to the north of Great Bear Lake, will be found

* One of the most marked examples of the influence of salinity upon Oceanic phenomena is offered at the mouth of the La Plata, where a light, fresh-watcr delta overlies the southern Braziliin current, which only reappears on the coast of Patagonia. 
to intersect the heights between the Sea of Okhotsk and the Arctic Ocean. The River Lena avoids it by turning towards the east, and breaks through it only at Yakutsk; the Kengui and Vilyui have a similar course; the upper and middle Tunguska, as well as the Ob, do so likewise-but towards the west-finally breaking through, the former below Tungusk, the latter below 'Troitskoi. All these rivers, as well as the heights running along them, conform to the direction of our circle. Further west the circle intersects the culminating points of the northern Ural, separates Lake Onega from the White Sea, and crossing the Gulf of Bothnia where it is narrowest (at Wasa), continues to Trondheim.

It then crosses Iceland longitudinally, strikes Cape Tycho Brahe on the coast of Greenland, and crosses the narrowest parts of Davis Strait and Fox Channel. Chesterfield Inlet, Dease and Simpson Strait, the Coronation Gulf and the northwest coast of America as far as Cape Barrow, mark out its return to Behring Strait.

The circle described I look upon as the centre axis of an annular mountain chain surrounding the whole of the Polar basin, and within (as on the moon) there may be traced three similar chains of smaller dimensions.

The first of these passes through Cape Brewster (in Scoresby Sound, East Greenland), Jan Mayen, the west coast of Spitzbergen, Mount Parry, Napoleon Point, the shore of Kennedy Channel, and the eastern shore of Smith Sound to Prince Regent Sound.

Of the second annular chain we are able to trace only the western shore of Prince Patrick Island, Barrow Point, Wrangel Land, and the Kotelnoi Islands.

The third chain can be traced more fully. Starting from the southern extremity of Spitzbergen it passes through Bear Island, Hammerfest, and along the southern bow-shaped coast of the White Sea, then joins the first of our chains, crosses the heights between $\mathrm{Ob}$ and Yenisei, and strikes the long-necked cape Chelyuskin.

Within this latter chain there are again several others of a subordinate order.

One of these passes through the whole of Spitzbergen, the Bear Island, North Cape, along the east coast of Lapland, the Kanin Peninsula, the south coast of the Kara Sea as far as White Island, and thence crosses over to the newly discovered Francis-Joseph Land, which thus forms part of the circumference of an annular mountain chain.

A second annular chain followed Novaya Zemlya, embraced the crooked arm of the sea at the mouth of the $(0 b$ and, passing 
through White and Waigat Islands, enclosed the basin of the Kara Sea.

The East Spitzbergen Sea likewise constitutes such a subordinate basin, bounded by Stans Foreland, the North Cape and Novaya Zemlya.

The annular chains enable us to determine the positions of the submarine plateaux separating the ocean basins. These plateaux are nine in number and extend as follows:-

1. From the North Cape by way of Bear Island to Spitzbergen.

2. From East Lapland to Novaya Zemlya.

3. From Admiralty Peninsula to Novaya Zemlya and King Charles Land.

4. From the southern extremity of Novaya Zemlya, by way of Waigat Island, to the main land of Siberia.

5. From Novaya Zemlya to White Island.

6. From the northern extremity of Novaya Zemlya to the coast of Siberia East of the Ob and Yenisei mouths.

7. From White Island, past the north-east cape of Novaya Zemlya, to Francis-Joseph Land.

8. From Francis-Joseph Land to Spitzbergen.

9. From Cape Chelyuskin to the north cape of Spitzbergen.

Francis-Joseph Land, Gillis Land, King Charles Land, and Spitzbergen, probably constitute a single group of islands.

Where three of these basins meet, a triangular plateau will be met with, and in these positions land, or at all events a shallow sea, are likely to be discovered.

If we compare the unknown space between Spitzbergen and Behring Strait with the Adriatic, or with other portions of the ocean, we are able to trace many analogies, and these enable us to form deductions respecting the discoveries likely to be made there.

Speaking generally, the whole area under consideration will probably turn out to be a gulf rounded off at the end, similarly to the Adriatic; and as the Po enters the latter, so will the warm China current passing through Behring Strait be found enter the former.

Compared with its vast area, the entrance to this Arctic gulf is but narrow. Norway and Greenland occupy the same positions with respect to it as do Brindisi and Capo Linguetto with respect to the Adriatic, and Pelagosa Island, lying within the entrance of the latter, has its counterpart in the Spitzbergen group of islands. As in the Adriatic, where the current flows north along the eastern shore and returns south along the western, so in the Arctic basin, where the warm current flows north along the coast of Norway, whilst a cold current is discharged in a southerly direction along the Greenland coast. 
In our remarks on Oceanic circulation we have proceeded north as far as the submarine plateau connecting Spitzbergen and the North Cape, and will now continue our investigation.*

The submarine plateau just referred to is crossed by a current flowing round North Cape and along the Lapland coast. This current, on reaching the eastern termination of the East Spitzbergen Sea, strikes against Novaya Zemlya, follows it as far as the submarine plateau, joining that island to King Charles Land; and it is then deflected towards the north and west in the direction of Spitzbergen. A portion of it, however, crosses the plateau, and has been traced as far as Orange Island and beyond (see 'Mittheilungen,' 1871, Plate 12); it then turns south, and forms an eddy or circuit-current in the Kara Sea. The latter has been found free from ice to the north of White Island, and of the $\mathrm{Ob}$ and Yenisei mouths, and the temperature of the surface-water in September exceeded $6^{\circ}$ Cent. ('Mittheilungen,' 1872, Plate 19).

The left branch of the current is, however, deflected by the submarine plateau connecting. White Island with Francis-Joseph Land and Spitzbergen (see Plate IV.), and, after having flowed for a certain distance towards the north-east, it turns back to the north and west, and forms a circuit-current extending to Cape Nassau.

This circuit-current explains the involuntary voyage of the Tegethoff, and led to the discovery of Francis-Joseph Land. When that vessel had reached the bifurcation of the main current, it found itself in an eventful situation. Had fate guided it into that branch of the current which flows past the north cape of Noraya Zemlya into the next basin, it would either have got into the power of another circuit-current produced by the submarine plateau stretching north from Cape Chelyuskin, or it might have crossed that plateau likewise and entered the great Polar basin, when currents would have carried it north of New Siberia, Wrangel Land, and Prince Patrick Island, right over to the North Yole, back to Chelyuskin!

The second branch of the current under consideration crosses the submarine plateau connecting Grant's Land and Cape Chelyuskin, and descends along the north and east coasts of Greenland towards Iceland.

The warm Japanese current enters the Polar basin, and the cold easterly currents running between the North American islands are discharged from it into Baffin Bay.

This great basin, no doubt, has its minor basins, and perhaps

* Consult for' what follows the maps in Peternann's 'Mittheilungen' for 186, s to $187 t$. 
islands, but the facts at our command are not sufficient to enable us to make deductions with respect to them.

In its main features we may suppose it to resemble the basins of the North and South Atlantic, the centre being open, with scattered islands, like the Azores, Bermulas, Ascension, St. Helena, Trinidad, and Tristan da Cunha, scattered along its margins.

We might further suppose that the central group of islandsconsisting of Spitzbergen, Francis-Joseph Land, and, perhaps, some undiscovered Polar land, which is separated from Siberia by an arm of the sea, has some connection with Greenland or North America; but, if this were the case, the large masses of ice encountered on the east coast of Greenland must originate to the south of Francis-Joseph Land and Spitzbergen, which they certainly do not; and we may, therefore, suppose that a wide channel connects the sea to the west of Spitzbergen with the interior Polar basin, through which they find an outlet.

When Lieutenant Payer returned from Eastern Greenland I showed him these my comparisons and deduction. I observed to him that a direct westerly route appeared to offer but few chances of success, but that, by going eastward, in the direction of the currents, it was more easily attainable. He seemed to agree with me.

Subsequently, on May 9th, 1871, I exhibited my diagrams at a meeting of the Vienna Geographical Society, of which : report is to be found in the 'Mittheilungen' of that body, Part VI., p. 304.

The accidental discovery of Francis-Joseph Land has not led to a final solution of the Arctic question, but furnishes facts which enable us to infer the unknown from the known, and whether discoverers add to our store of knowledge under the equator or within the Arctic circle, we are equally indebted to their courage and endurance.

In looking to the further pursuit of Arctic exploration, the following considerations may be deserving of attention.

Crystallization is promoted by contact with solid objects. Hence the coasts are fringed, as it were, with a band of ice, and where the arms of the sea are narrow, even they become occasionally covered with ice to their whole extent.

Vessels, consequently, find it difficult to approach the coast.

On the other hand, the centre of the sea, for instance that of East Spitzbergen, is generally free from ice during summer. On this account coasting voyages are not to be recommended.

Motion is the enemy of crystallization, and we do not yet know what degree of cold would suffice to cover extensive 
surfaces of agitated water with a sheet of ice. Open water has been discovered at the northern extremities of Francis-Joseph Land, Spitzbergen and Grant's Land; and it is therefore possible, nay probable, that the centre of the great Polar basin is periodically free from ice.

The temperature in the highest latitudes hitherto reached admits of animal and vegetable life, and it is therefore hardly likely that $7^{\circ}$ farther to the north, that is at the Pole itself, it should be quite extinct. It appears that a low daily temperature not interrupted by cold nights, may exercise as favourable an influence upon the growth of plants as a fluctuating higher temperature succeeded by cold nights.

Several routes lead into the Polar basins, but explorers should in every case follow the ocean-currents and not proceed in a contrary direction. They should do as the ferryman, who first ascends one bank, and then allows himself to be drifted to the other, and not sail right across.

Nor is the shortest route always the most advantageous, for the aid of currents may compensate for long detours.

We have already seen that one of the routes leads past Novaya Zemlya, the north cape of which has already been doubled by Johannesen. The same route might be reached through the Kara Sea or from the mouth of the Ob or Yenisei. Having succeeded in gaining the sea to the east of Novaya Zemlya, it becomes necessary to double Cape Chelyuskin, in order to enter the great Polar basin. There is another route into this basin from the mouth of the Lena.

The route through Behring Strait would not probably oppose great difficulties to an attempt at reaching the current flowing past Patrick Island to the North Pole.

Hall, amongst all explorers, has up to the present time attained the lighest latitude, and as he found an open sea he might have succeeded in reaching the Pole itself had he kept to the west instead of to the east. There is probably no land between Hall's furthest and the Pole, but the direct route, for some distance, runs counter to, or across the current which carries such masses of ice down the east coast of Greenland, and this current might create great, if not insurmountable difficulties to an explorer.

If my drawings and inferences are not altogether erroneous, Patrick Island, or the North Cape of Spitzbergen, would appear to offer the most advantageous base for penetrating to the Pole. If the Spitzbergen be chosen, the ship would be carried by a current to the north-west, and, having crossed the submarine plateau extending between Grant's Land and Cape Chelyuskin, the attainment of the North Pole would prove comparatively 
easy. Parry's route was too direct northerly; hạd he penetrated a little further, he might have discovered land.

In concluding these remarks on the probable nature of the Polar Regions, I must crave your kind indulgence on account of the difficulties attending the subject.

III.-Journey to Umzila's, South-East Africa, in 1871-1872. By Mr. St. Vincent Enskine, Special Commissioner from the Natal Government to Umzila, King of Gasa.

[ABRIDGED.]

[Read, January 11th, 1875.]

AT the outset it will not be necessary to remark-as I shall farther on-upon Captain Elton's report of his journey. It is sufficient to premise that I differ from him in many particulars, especially as to the navigability of the Limpopo. Contemporaneously with my journey, of which this is an account, Mr. Carl Mauch, the noted German explorer, with whom I had the pleasure of travelling over some part of my former tour, discovered the ruins of Zimbabye or Zimbaoe, supposed to be the ancient city of the Queen of Sheba, which name is similar to that of the river Saba or Sabia, upon whose banks (or rather those of an affluent, named Tokwe) these ruins are said actually to stand.

Mr. Mauch's researches place these ruins within 42 miles of my calculated position when at Umzila's kraal, which was determined by several celestial observations by the stars and sun, to be in lat. $20^{\circ} 23^{\prime} \mathrm{s}$., and long. E. $32^{\circ} 30^{\prime}$ by dead reckoning; about 25 miles to the east of the Sabi River. I neither heard anything of the ruins after repeated inquiries, nor of Mr. Mauch himself. I am therefore surprised to read in his account that he supposed himself only six days' walk from Sofala; whereas the natives informed me that I was at least eight days walk distant from Sofala, Mr. Mauch being still to the westward of my position by his own account, i.e. west of the Sabi. Unfortunately the lunar distances determining the true longitude of Umzila's kraal taken by me (being eighteen sights, or three sets east and three sets west), have been totally lost in a waggon, in crossing a flooded river in Natal, together with all my notebooks except the map.

The following Journal is therefore composed entirely from memory. Such latitudes as are given are partly from recollec- 